\title{
ANALISIS KEPUASAN KONSUMEN TERHADAP HASIL OLAHAN LAUT (UKM KEPITING) DI KOTA TARAKAN
}

\author{
ANALYSIS OF CONSUMER SATISFACTION ON PROCESSED \\ SEAFOOD (UKM KEPITING) IN TARAKAN CITY
}

\begin{abstract}
Meylin Rahmawati
Program Studi Manajemen, Fakultas Ekonomi Universitas Borneo Tarakan rahmawatimeylin@gmail.com
\end{abstract}

\begin{abstract}
Abstrak: Salah satu sumber daya laut yang berpotensi di Kota Tarakan adalah Kepiting, yang mana budidaya kepiting itu sendiri memiliki tingkat permintaan pasar yang tinggi. Sehingga terdapat banyak UKM yang menjadikan kepiting ini sebagai salah satu sumber daya yang digunakan produk dari UKM itu sendiri. Adapun penelitian ini dilakukan, bertujuan untuk mengetahui dan menganalisis pengaruh harga dan kualitas terhadap tingkat kepuasan konsumen dalam mengkonsumsi produk olahan kepiting. Sumber data yang digunakan didalam penelitian ini adalah data primer dan sekunder. Pengumpulan data primer dilakukan dengan cara melakukan wawancara langsung dengan responden dengan pertanyaan yang telah terdaftar terlebih dahulu. Hasil menunjukkan bahwa variabel secara bersama-sama (simultan) didapatkan hasil bahwa terdapat pengaruh secara simultan antara harga dan kualitas.
\end{abstract}

Kata kunci: UKM, Produk Olahan Kepiting, Kepuasan Konsumen

Abstract: One of the potential marine resources in Tarakan City is Crab, where crab cultivation itself has a high level of market demand. So there are many SMEs that make this crab as one of the resources used by the products of the SMEs themselves. This research was conducted, aiming to determine and analyze the effect of price and quality on the level of consumer satisfaction in consuming processed crab products. Sources of data used in this study are primary and secondary data. Primary data collection is done by conducting direct interviews with respondents with questions that have been registered in advance. The results show that the variables simultaneously (simultaneously) show that there is a simultaneous influence between, price and quality. 
Keywords: UKM, Crab Processed Products, Consumer Satisfaction

\section{PENDAHULUAN}

Daerah pesisir merupakan daerah yang sangat terkait dengan hajat hidup banyak orang, terutama masyarakat yang bertempat tinggal di daerah tersebut. Daerah pesisir adalah daerah pertemuan antara pengaruh daratan dan lautan, ke arah darat sampai pada daerah masih adanya pengaruh perembesan air laut dan angin laut, dan ke arah laut sampai pada daerah masih ada pengaruh air tawar yang memiliki beragam sumberdaya (California Environmental Associates, 2018).

Secara sosial ekonomi wilayah pesisir merupakan tempat aktivitas manusia bersosialisasi, yaitu kepemerintahan, sosial, ekonomi budaya, pertahanan dan keamanan (Clifton, Tonts, \& Boruff, 2007; Chen \& Zheng, 2016). Daerah pesisir merupakan wilayah daratan dan wilayah laut yang bertemu di garis pantai, di mana wilayah daratan mencakup daerah yang tergenang atau tidak tergenang air yang dipengaruhi oleh proses-proses laut seperti pasang surut, angin laut, dan intrusi air laut (Apridar Et All, 2011). Sedangkan wilayah laut mencakup perairan yang dipengaruhi oleh proses-proses alami daratan seperti sedimentasi dan aliran air tawar ke laut serta perairan yang dipengaruhi oleh kegiatan manusia di darat. Berdasarkan dua definisi di atas, daerah pesisir mencakup dua wilayah utama, yaitu wilayah daratan 2 dan wilayah laut, yang menyimpan berbagai macam sumber daya, baik yang ada di daratan maupun yang ada di lautan.

Daerah pesisir memiliki berbagai macam potensi, meliputi sumber makanan utama yang mengandung protein (khususnya protein hewani yang berasal dari ikan, udang dan sejenisnya), kekayaan minyak bumi, gas dan mineral lainnya yang berpotensi dalam bidang pertambangan, potensi pariwisata, pemukiman dan pengembangan industri (David, Leandro, Almeida , \& Estupiñán, 2015). Oleh karena itu, daerah pesisir menjadi daerah yang strategis untuk dikelola dalam rangka memenuhi hajat hidup masyarakat, terutama berkaitan dengan pembangunan ekonomi yang dapat menunjang perekonomian masyarakat sekitar, pemerintah daerah maupun pihak-pihak lainnya (FAO, 2005; Cahaya, 2015). Pengelolaan daerah pesisir tentu saja melibatkan banyak pemangku kepentingan (stakeholders), sehingga berbagai kepentingan pun bertemu atas nama pembangunan daerah pesisir ( Fragouli \& Theodoulou, 
2015; Zamroni, Apriliani, Yusuf, \& Kurniasari, 2019).

\section{Rumusan Masalah}

Adapun permasalahan yang telah dirumuskan adalah sebagai berikut:

a. Bagaimana tingkat kepuasan konsumen terhadap produk?

b. Atribut apa saja yang berpengaruh pada kepuasan konsumen?

\section{Tujuan Dan Manfaat Penelitian}

\section{Tujuan Khusus}

Tujuan khusus penelitian ini adalah sebagai berikut:

1. Mengidentifikasi tingkat kepuasan konsumen terhadap produk

2. Mengidentifikasi atribut yang berpengaruh pada kepuasan konsumen

3. Mengidentifikasi atribut prioritas yang berpengaruh pada kepuasan konsumen

\section{Manfaat Penelitian}

Manfaat penelitian ini adalah:

a. Menyediakan informasi tingkat kepuasan konsumen terhadap produk.

b. Menyediakan informasi atribut yang berpengaruh pada kepuasan konsumen.

c. Menyediakan informasi atribut yang berpengaruh pada kepuasan konsumen

d. Memberikan informasi atribut prioritas yang berpengaruh pada kepuasan konsumen

e. Rekomendasi kebijakan berdasarkan atribut prioritas

\section{TINJAUAN PUSTAKA}

\section{DefinisiUKM}

Definisi UMKM menurut Undang-Undang No. 20 Tahun 2008 tentang Usaha Mikro, Kecil dan Menengah Bab 1 Pasal 1: Usaha mikro adalah usaha produktif milik orang perorangan dan atau badan usaha perorangan yang memenuhi kriteria usaha mikro. Usaha kecil adalah usaha produktif yang berdiri sendiri, yang dilakukan oleh perseorangan atau badan usaha bukan merupakan anak cabang perusahaan yang dimiliki, dikuasai, atau menjadi bagian baik langsung maupun tidak langsung dari usaha menengah atau besar yang memenuhi kriteria usaha kecil. Usaha menengah adalah usaha ekonomi produktif yang berdiri sendiri, yang dilakukan oleh orang perorangan atau badan usaha yang bukan merupakan anak perusahaan atau cabang perusahaan yang dimiliki, dikuasai, atau menjadi bagian baik langsung maupun tidak langsung dengan Usaha kecil atau Usaha besar dengan jumlah kekayaan bersih atau hasil penjualan tahunan.

Definisi UMKM menurut Kementrian Koperasi dan UMKM dalam Aufar (2014:8) : Usaha Kecil 
(UK), termasuk usaha Mikro (UMI) adalah entitas usaha yang mempunyai kekayaan bersih paling banyak Rp. 200.000.000, tidak termasuk tanah dan bangunan tempat usaha dan memiliki penjualan tahunan paling banyak $\mathrm{Rp}$. 1.000.000.000. Sementara itu, Usaha Menengah (UM) merupakan entitas usaha milik warga negara Indonesia yang memiliki kekayaan bersih lebih besar dari Rp. 200.000 .000 s.d. Rp.10.000.000 tidak termasuk tanah dan bangunan.

Definisi UMKM menurut Bank Indonesia Usaha kecil adalah usaha produktif milik warga negara Indonesia, yang berbentuk badan usaha orang perorangan, badan usaha yang tidak berbadan hukum, atau badan usaha berbadan hukum seperti koperasi; bukan merupakan anak perusahaan atau cabang yang dimiliki, dikuasai atau berafiliasi, baik langsung maupun tidak langsung dengan usaha menengah atau besar (Aufar, 2014). Memiliki kekayaan bersih paling banyak $\mathrm{Rp}$. 200.000.000, tidak termasuk tanah dan bangunan atau memiliki hasil penjualan paling banyak Rp. 200.000.000 per tahun, sedangkan usaha menangah, merupakan usaha yang memiliki kriteria aset tetapnya dengan besaran yang dibedakan antara industry manufaktur (Rp. 200.000.000 s.d. Rp. 500.000.000) dan non manufaktur (Rp. 200.000.000 s.d. Rp. 600.000.000). Berdasarkan definisi di atas dapat dikatakan bahwa UMKM adalah usaha milik orang perorangan badan usaha yang bukan merupakan anak atau cabang dari perusahaan lain dengan kriteria memiliki modal usaha yang memiliki batasan-batasan tertentu.

\section{Kepiting}

Kepiting adalah binatang anggota krustasea berkaki sepuluh dari upabangsa (infraordo) Brachyura, yang dikenal mempunyai "ekor" yang sangat pendek (bahasa Yunani: brachy $=$ pendek, ura $=$ ekor), atau yang perutnya (abdomen) sama sekali tersembunyi di bawah dada (thorax). Tubuh kepiting dilindungi oleh cangkang yang sangat keras, tersusun dari kitin, dan dipersenjatai dengan sepasang capit. Ketam adalah nama lain bagi kepiting.

Kepiting terdapat di semua samudra dunia. Ada pula kepiting airtawar dan darat, khususnya di wilayah-wilayah tropis. Rajungan adalah kepiting yang hidup di perairan laut dan jarang naik ke pantai, sedangkan yuyu adalah ketam penghuni perairan tawar (sungai dan danau). Kepiting beraneka ragam ukurannya, dari ketam kacang, yang lebarnya hanya beberapa milimeter, hingga kepiting laba-laba Jepang, dengan rentangan kaki hingga 4 meter.

Jenis dan Ukuran Kepiting Bakau (Scylla sp.) yang diperdagangkan di Kota Tarakan 
memiliki jenis dan ukuran yang bervariasi sesuai dengan permintaan konsumen di pasar. Pengelompokkan kepiting bakau ini secara umum didasarkan pada jenis, kelengkapan anggota tubuh, kekerasan cangkang, ukuran berat dan persentase telurnya. Berikut ini kelompok kepiting dan kriteria yang diperdagangkan di KotaTarakan (Dinas Perikanan dan Kelautan, 2019).

\section{KepuasanKonsumen}

Konsep kepuasan pelanggan tidak mudah didefinisikan. Ada berbagai macam pengertian yang diberikan oleh para ahli Tjiptono (2008), kepuasan pelanggan adalah respons pelanggan terhadap evaluasi ketidaksesuaian yang di rasakan anatara harapan sebelumnya atau norma kinerja lainnya dan kinerja aktual produk yang di rasakan setelah pemakaiannya. Kotler (2009), kepuasan pelanggan adalah tingkat perasaan seseorang setelah membandingkan kinerja atau hasil yang ia rasakan di bandingkan dengan harapannya. Menurut Sunarto (2003), kepuasan pelanggan merupakan perasaan senang atau kecewa setelah membandingkan antara persepsi/kesannya terhadap kinerja/harapan. Jika kinerja memenuhi harapan, pelanggan puas. Jika melebihi harapan, pelanggan amatpuas.

Menurut PJ. Johnson dalam Purwoko (2000) mengemukakan kepuasan seorang pelanggan dapat terlihat dari tingkat penerimaan pelanggan yang didapatkan. Menurut Gaspersz (2005), faktor-faktor yang mempengaruhi kepuasan dan ekspektasi pelanggan terdiri dari Kebutuhan dan keinginan yang berkaitan dengan hal-hal yang dirasakan pelanggan ketika ia sedang mencoba melakukan transaksi dengan produsen jasa. Konsep dan teori mengenai kepuasan pelanggan telah berkembang pesat dan telah mampu diklasifikasikan atas beberapa pendekatan. Salah satu pendekatan yang paling populer yang berhubungan dengan kepuasan pelanggan adalah teori The Expectancy Disconfirmation Model (Gremler et al., 2012).

\section{Penelitian Terdahulu}

Dalam penelitian terdahulu oleh Willy Wijaya (2017) “Analisa Pengaruh Makanan Terhadap Kepuasan Konsumen di Yoshinoya Galaxy Mall Surabaya”. Berdasarkan hasil analisis dapat diperoleh kesimpulan sebagai berikut: pertama Berdasarkan hasil analisis dan pengujian hipotesis dapat dikatakan bahwa variabel kualitas makanan yang terdiri dari freshness, presentation, well cooked, dan variety of food secara simultan dan parsial terbukti memiliki pengaruh yang positif dan signifikan terhadap kepuasan konsumen di Yoshinoya Galaxy Mall Surabaya. Hasil ini menunjukkan bahwa semakin baik 
kualitas makanan yang disajikan oleh restoran Yoshinoya Galaxy Mall Surabaya, maka akan semakin tinggi kepuasan yang dirasakankonsumen.

\section{Hipotesis}

Dalam penelitian ini, peneliti menggunakan variabel-variabel pendukung seperti Price /harga dan Quality /Kualitas. Hipotesis merupakan jawaban sementara atas suatu persoalan yang masih perlu dibuktikan kebenarannya dan harus bersifat logis, jelas, dan dapat diuji. Hipotesis yang diajukan dalam penelitian ini adalah:

1. Diduga terdapat pengaruh secara parsial antara Price/Harga dan Quality/Kualitas terhadap kepuasan konsumen terhadap hasil tangkap laut.

2. Diduga terdapat pengaruh secara simultan antara Price/Hargadan Quality/Kualitas terhadap kepuasan konsumen terhadap hasil tangkap laut.

\section{METODOLOGI PENELITIAN}

\section{Definisi Operasional dan PengukuranVariabel}

Untuk menjelaskan istilah yang digunakan dan menghindari perluasan masalah dalam penelitian ini, maka dibuat variabel operasionalnya sebagai berikut:

1. Kepuasan konsumen yaitu keinginan dan kebutuhan yang berkaitan dengan hal-hal yang dirasakan konsumen ketika para konsumen mengosumsi olahankepiting.

2. Price/Harga yaitu biaya yang dikenakan kepada konsumen untuk mendapatkan olahankepiting.

3. Quality/Kualitas yaitu tingkat baik buruknya olahan kepiting untuk dikonsumsi olehkonsumen.

Jenis Data Rincian yang diperlukan

\section{Jenis dan Sumber Data}

a. Jenis Data

Data yang digunakan dalam menganalisis pengaruh

Quality/kualitas dan Price/Harga menggunakan data jenis cross section yaitu data yang dikumpulkan pada waktu tertentu untuk menggambarkan keadaan pada waktu tertentu.

b. Data primer merupakan data penelitian yang diperoleh secara langsung dari sumber asli (tidak melalui perantara). Data primer secara khusus dikumpulkan oleh peneliti untuk menjawab pertanyaan penelitian. Dalam penelitian ini data diambil berdasarkan kuesioner yang diberikan kepada responden.

\section{Teknik Pengumpulan Data}

Teknik pengumpulan data yang digunakan dalam penelitian ini adalah: 
1. Penelitian Kepustakaan (library research) yaitu teknik pengumpulan data dengan cara mengumpulkan data-data yang berupa informasi maupun sumber bacaan lain yang terkait dengan penelitian.

2. Penelitian lapangan (field research) yaitu mengumpulkan data primer, dimana peneliti secara langsung terjun ke lapangan untuk melakukan pengamatan serta wawancara maupun mencatat untuk memperoleh dan atau keterangan yang diperlukan. Selanjutnya untuk lebih memudahkan wawancara kepada responden maka dibantu dengan daftar pertanyaan yang disusun secara sistematis yang berkaitan dengan kegiatan konsumen.

3. Kuesioner yaitu teknik pengumpulan data dengan sejumlah daftar pertanyaan yang diberikan kepada responden untuk mendapatkan jawaban langsung dariresponden.

Populasi dan Sampel

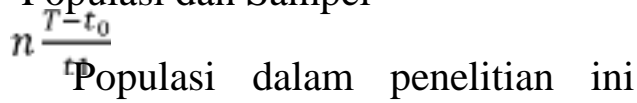
adalah para masyarakat yang mengkonsumsi hasil olahan laut (kepiting) yang tidak diketahui secara pasti.

Sampel penelitian meliputi jumlah elemen (responden) yang lebih besar dari persyaratan minimal sebanyak 30 elemen/responden. Menurut Guilford (1987) dalam
Supranto (2006), dimana semakin besar sampel (makin besar nilai nbanyaknya elemen sampel) akan memberikan hasil yang lebih akurat.

Metode sampling yang digunakan adalah metode random sampling, adapun Menurut Sugiyono (2001) teknik simple random sampling adalah teknik pengambilan sampel dari anggota populasi yang dilakukan secara acak tanpa memperhatikan strata yang ada dalam populasi itu. Sedangkan Menurut Kerlinger (2006), simple random sampling adalah metode penarikan dari sebuah populasi atau semesta dengan cara tertentu sehingga setiap anggota populasi atau semesta tadi memiliki peluang yang sama untuk terpilih atau terambil.

Untuk menentukan jumlah sampel yang diambil adalah dengan menggunakan rumus linier time function, jumlah sampel ditentukan berdasarkan waktu yangefektif yang digunakan untuk melakukan penelitian, karena populasi tidak diketahui.

Dimana $: \mathrm{n}=$ Jumlah Sampel yang Terpilih

$\mathrm{T}=$ Waktu yang tersedia untuk penelitian $(6$ hari $x 12$ Jam $=72$ jam $)$

$\mathrm{T}_{0}=$ Waktu pengambilan sampel (6hari $\times 8$ jam $=48$ jam)

$\mathrm{t}_{1}=$ Waktu yang digunakan untuk mengisi kuesioner $(1 / 4$ jam $=0,25$ jam) 


\section{Alat Analisis Data}

\section{Skala Likert}

Menurut Sugiyono (2009)

Skala likert digunakan untuk mengukur sikap, pendapat dan persepsi seseorang atau sekelompok orang tentang fenomena sosial. Skala likert yang diukur kemudian dijabarkan menjadi indikator variabel dan dijadikan sebagai titik tolak untuk menyusun item instrument yang berupa pernyataan. Jawaban setiap item instrument yang menggunakan skala likert mempunyai gradasi dari sangat positif sampai sangat negatif.

Skala pengukuran variabel dalam penelitian ini mengacu pada skala likert (likert scale), dimana masinng-masing dibuat dengan menggunakan skala 1-5 kategori. Guna memberi skor terhadap jawaban yang diperoleh dari responden, peneliti menggunakan skala kategori (category scale) dengan kriteria yang masing-masing jawaban diberi skor atau bobot yaitu banyaknya skor antara 1 sampai 5 .

\section{Analisis Deskriptif}

Analisis deskriptif berupa analisis tabel yang digunakan untuk menganalisis dan menginterpretasikan data secara langsung sehingga dapat diambil kesimpulan.

Data yang ditabelkan berupa kepuasan konsumen terhadap olahan kepiting berdasarkan harga dan kualitas. Data deskriptif ini akan dikemukakan dengan tabel data maupun distribusi frekuensi.

Analisis deskriptif persentase digunakan untuk mendeskripsikan data pada instrumen kondisi kepuasan konsumen terhadap hasil olahan kepiting. Perhitungan digunakan untuk mengetahui persentase skor jawaban dari masingmasing pengunjung yang telah diambil sebagai sampel dengan melihat rumus sebagaiberikut:

$$
\%=\frac{n}{N} \times 100 \%
$$

Keterangan : $\mathrm{n}$ : Nilai yang diperoleh $\mathrm{N}$ : Nilai Total

$\%$ : Tingkat keberhasilan yang dicapai

\section{Analisis Regesi Linear Berganda}

Analisis regresi merupakan salah satu analisis yang bertujuaan untuk mempengaruhi pengaruh suatu variabel terhadap variabel lain. Hubungan tersebut terikat $\mathrm{Y}$ dengan satu atau lebih variabel bebas $\mathrm{X}_{1}$, $\mathrm{X}_{2}, \ldots, \mathrm{X}_{\mathrm{n}}$ dalam analisis regresi pola hubungan antar variabel diekspresikan dalam sebuah persamaan regresi yang diduga berdasarkan data sam

Dalam analisis regresi, variabel yang mempengaruhi disebut Independent Variabel (variabel bebas) dan variabel yang dipengaruhi disebut Dependent Variabel (variabel terikat), Jika dalam persamaan disebut sebagai persamaan regresi sederhana, 
sedangkan jika variabel bebasnya lebih dari satu, maka disebut sebagai persamaan regresi berganda. Untuk menganalisis kepuasan pengunjung yang dipengaruhi oleh price/harga dan Quality/Kualitas. , dapat diformulasikan sebagai berikut:

$\mathrm{Y}=\mathrm{f}\left(\mathrm{X}_{1}, \mathrm{X}_{2}\right)$

$\mathrm{Y}=$ Kepuasan/penilaian konsumen olahan kepiting

$\mathrm{X}_{1}=$ price $/$ harga

$\mathrm{X}_{2}=$ quality / kualitas

Dari formulasi di atas, di transformasikan ke dalam regresi linier berganda sebagai berikut:

$\mathrm{Y}=\beta_{0}+\beta_{1} \mathrm{X}_{1}+\beta_{2} \mathrm{X}_{2} \varepsilon$
Keterangan :

$\mathrm{Y}=$ Kepuasan/penilaian konsumen

$\beta_{0}=$ Konstanta

$\beta_{1}=$ Besarnya pengaruh price/harga terhadap kepuasan konsumen

$\beta_{2}=$ Besarnya pengaruh quality/ kualitas terhadap kepuasan konsumen $\mathrm{X}_{1}=$ price $/$ harga $\mathrm{X}_{2}=$ quality / kualitas $\varepsilon=$ Error Term

HASIL DAN PEMBAHASAN

Deskripsi Responden Penelitian

Rekapitulasi Karakteristik Responden

\begin{tabular}{|c|c|c|}
\hline \multicolumn{2}{|c|}{ Karakteristik } & Persentase (\%) \\
\hline \multirow[t]{2}{*}{ Jenis Kelamin } & Laki-laki & 37.5 \\
\hline & Perempuan & 62 \\
\hline \multirow[t]{5}{*}{ Umur } & $\leq 20$ Tahun & 6,25 \\
\hline & $\begin{array}{l}21 \text { Tahun }-25 \\
\text { Tahun }\end{array}$ & 46,875 \\
\hline & $\begin{array}{l}26 \text { Tahun }-30 \\
\text { Tahun }\end{array}$ & 12,5 \\
\hline & $\begin{array}{l}31 \text { Tahun }-35 \\
\text { Tahun }\end{array}$ & 6,25 \\
\hline & $>35$ Tahun & 28,125 \\
\hline \multirow[t]{5}{*}{ Pendidikan } & SMP & 28,125 \\
\hline & SMA & 43,75 \\
\hline & D3 & 3,125 \\
\hline & $\mathrm{S} 1$ & 25 \\
\hline & SMP & 28,125 \\
\hline \multirow[t]{5}{*}{ Jenis Pekerjaan } & PNS & 6,25 \\
\hline & Pelajar/Mahasiswa & 28,125 \\
\hline & Pegawai Swasta & 6,25 \\
\hline & Wiraswata & 31,25 \\
\hline & Lain-lain & 28,125 \\
\hline
\end{tabular}




\begin{tabular}{|l|l|c|}
\hline \multirow{4}{*}{$\begin{array}{l}\text { Distribusi } \\
\text { Responden } \\
\text { Berdasarkan }\end{array}$} & Media Cetak & 12,5 \\
\cline { 2 - 3 } $\begin{array}{l}\text { Informasi Objek } \\
\text { Hasil Olahan }\end{array}$ & Ledia elektronik & 18,75 \\
\cline { 2 - 3 } & Informasi lisan & 40,625 \\
\cline { 2 - 3 } $\begin{array}{l}\text { Distribusi } \\
\text { Responden } \\
\text { Berdasarkan } \\
\text { Berapa Kali } \\
\text { Mengonsumsi }\end{array}$ & Pertama kali & 28,125 \\
\cline { 2 - 3 } & 2 kali & \\
\cline { 2 - 3 } & 3-5 kali & \\
\hline
\end{tabular}

Sumber: Data Primer, 2020

Berdasarkan pada tabel diatas terlihat bahwa sebagian besar responden dalam penelitian ini adalah para konsumen yang mengkonsumsi hasil olahan laut yaitu kepiting sebanyak 32 orang. Sebagian besar responden dalam penelitian ini adalah para masyarakat yang mengkonsumsi hasil olahan laut yaitu kepiting di Kota Tarakan sebanyak 32 orang, berdasarkan usia di bawah atau sama dengan 20 tahun sebanyak 2 orang $(6,25 \%), 21$ sampai 25 tahun sebanyak 15orang (46,875\%), 26 sampai 30 tahun sebanyak 4 orang $(12,5 \%), 31$ sampai 35 tahun sebanyak 2 orang $(6,25 \%)$, dan lebih dari 35 sebanyak 9 orang $(28,125 \%)$.

Masyarakat yang mengkonsumsi hasil olahan laut yaitu kepiting di Kota Tarakan sebanyak 32 orang, berdasarkan tingkat pendidikan terakhir SMP sebanyak 9 orang $(28,125 \%)$, SMA sebanyak 14 orang $(43,75 \%)$, D3 sebanyak 1 orang
$(3,125 \%), \quad$ S1 sebanyak 8 orang $(25 \%)$. Masyarakat yang mengkonsumsi hasil olahan laut yaitu kepiting sebanyak 32 orang, berdasarkan dengan pekerjaan utama sebagai PNS sebanyak 2 orang (6,25\%), pelajar /mahasiswa 9 orang $(28,125 \%)$, pegawai swasta sebanyak 2 orang $(6,25 \%)$, wiraswasta 10 orang $(31,25 \%)$, dan lain-lain 9 orang $(28,125 \%)$.

Di sisi lain, para konsumen yang mengkonsumsi hasil olahan laut yaitu kepiting sebanyak 32 orang, berdasarkan informasi objek hasil olahan media cetak sebanyak 4 orang $(12,5 \%)$, media elektronik sebanyak 6 orang $(18,75 \%)$, informasi lisan sebanyak 13 orang $(40,625 \%)$, dan lainnyasebanyak 9 orang $(28,125 \%)$. Sebagian besar responden dalam penelitian ini adalah para konsumen yang mengkonsumsi hasil olahan laut yaitu kepiting sebanyak 32 orang, berdasarkan berapa kali mengkonsumsi pertama kali 
sebanyak 0 orang $(0 \%), 2$ kalisebanyak 2 orang $(6,25 \%)$, 35kali sebanyak 2 orang $(6,25 \%)$, lebih dari 5 kali sebanyak 28 orang $(87,5 \%)$.

\section{Deskriptif Variabel Penelitian}

Penelitian ini mengambil variabel bebas yang diduga mempunyai pengaruh terhadap kepuasan konsumen terhadap hasil tangkap laut yaitu kepiting di kota Tarakan. Variabel bebas tersebut di antaranya adalah Harga/Price (X1) dan Kualitas/Quality (X2). Berikut analisis deskriptif setiap variabel bebas.

\section{Price / Harga}

Data tentang Price/Harga berdasarkan tanggapan responden yang diperoleh dari pengisian kuesioner oleh 32 reponden. Berdasarkan hasil analisis data diperoleh hasil sebagai berikut:

Distribusi Frekuensi Price/Harga

\begin{tabular}{|l|l|l|}
\hline Kriteria & Frekuensi & $\begin{array}{c}\text { Persentase } \\
(\mathbf{\%})\end{array}$ \\
\hline $\begin{array}{l}\text { Sangat } \\
\text { Setuju }\end{array}$ & 9 & 28,125 \\
\hline Setuju & 19 & 59,375 \\
\hline Netral & 4 & 12,5 \\
\hline $\begin{array}{l}\text { Tidak } \\
\text { Setuju }\end{array}$ & 0 & 0 \\
\hline $\begin{array}{l}\text { Sangat } \\
\text { tidak } \\
\text { Setuju }\end{array}$ & 0 & 0 \\
\hline Jumlah & $\mathbf{3 2}$ & $\mathbf{1 0 0}$ \\
\hline
\end{tabular}

Sumber: Data diolah, 2020
Berdasarkan tabel tersebut maka dapat disimpulkan bahwa untuk atraction/atraksi 9 responden $(28,125 \%)$ sangat setuju, 19 responden $(59,375 \%)$ setuju, 4 responden $(12,5 \%)$ Netral, 0 responden $(0 \%)$ tidak setuju, dan 0 responden $(0 \%)$ sangat tidak setuju. Maka dapat disimpulkan bahwa frekuensi terbesar ada pada frekuensi 19 responden $(59,375 \%)$ setuju.

\section{Quality/Kualitas}

Data tentang quality/kualitas diperoleh dari tanggapan 32 responden.

Distribusi Frekuensi Quality/ Kualitas

\begin{tabular}{|l|l|l|}
\hline Kriteria & Frekuensi & $\begin{array}{c}\text { Persentase } \\
(\%)\end{array}$ \\
\hline $\begin{array}{l}\text { Sangat } \\
\text { setuju }\end{array}$ & 19 & 59,375 \\
\hline Setuju & 7 & 21,875 \\
\hline Netral & 5 & 15,625 \\
\hline $\begin{array}{l}\text { Tidak } \\
\text { setuju }\end{array}$ & 1 & 3,125 \\
\hline $\begin{array}{l}\text { Sangat } \\
\text { tidak } \\
\text { setuju }\end{array}$ & 0 & 0 \\
\hline Jumlah & $\mathbf{3 2}$ & $\mathbf{1 0 0}$ \\
\hline
\end{tabular}

Sumber: Data diolah, 2020

Berdasarkan table di atas tersebut maka dapat disimpulkan bahwa untuk quality/kualitas 19 responden $(59,375 \%)$ sangat setuju, 7 responden $(21,875 \%)$ setuju, 5 
responden $(15,625 \%) \quad$ Netral, responden $1(3,125 \%)$ tidak setuju, dan 0 responden $(0 \%)$ sangat tidak setuju. Maka dapat disimpulkan bahwa frekuensi terbesar ada pada frekuensi 19 responden $(59,375 \%)$ sangat setuju.

\section{Uji Asumsi Klasik}

Uji asumsi klasik dimaksudkan untuk mengetahui apakah model regresi linier berganda yang digunakan dalam menganalisa penelitian telah menemui asumsi klasik atau tidak. Berikut beberapa penguji asumsi klasik yang dilakukan:

\section{Uji Multikulinieritas}

Deteksi

multikolinieritas

adanya

dipergunaka

inflaction factor), bila nilai VIF lebih besar dari 10 dan tolerance $<0,10$ maka variabel tersebut memiliki persoalan multikolinieritas dengan variabel bebas lainnya. Berikut dari uji multikolinieritas:

\section{Hasil Uji Multikulinieritas}

\begin{tabular}{|c|c|c|}
\hline \multirow[t]{2}{*}{ Model } & \multicolumn{2}{|c|}{$\begin{array}{l}\text { Collinearity } \\
\text { Statistics }\end{array}$} \\
\hline & $\begin{array}{l}\text { Toleranc } \\
\text { e }\end{array}$ & VIF \\
\hline Price/Harga & 0.600 & $\begin{array}{l}1.66 \\
6\end{array}$ \\
\hline $\begin{array}{l}\text { Quality/Kualit } \\
\text { as }\end{array}$ & 0.600 & $\begin{array}{l}1.66 \\
6\end{array}$ \\
\hline
\end{tabular}

dependent variabel: kepuasan
Tabel diatas menunjukkan nilai VIF (varian inflaction factor) ke dua variabel yaitu price/harga $\left(\mathrm{X}_{1}\right)$ sebesar 1.666, quality/kualitas $\left(\mathrm{X}_{2}\right)$ memiliki nilai VIF lebih dari10.

Sedangkan melihat dari nilai tolerance ke dua variabel memiliki nilai masing-masing yaitu price/harga $\left(\mathrm{X}_{1}\right)$ sebesar 0.600, quality/kualitas $\left(\mathrm{X}_{2}\right)$ sebesar 0.600 , Hal ini menunjukkan bahwa tolerance $>0,10$ hasil pengujian model regresi menunjukkan bahwa tidak ada gejala multikolinieritas dalam model regresi. Hal ini berarti bahwa semua variabel bebas tersebut layak digunakan sebagai predikator.

\section{Uji Heterokedastisitas}

Berdasarkan dengan uji glejser di Deteksi adanya heterokedastisitas dapat dilihat dengan mengamati angka signifikan, apabila angka signifikan lebih bsar dari 0,05 atau 5\% maka dikatakan tidak terjadi heterokedastisitas dan apabila nilai signifikan lebih kecil dari 0,05 atau 5\% maka dapat dikatakan bahwa terjadi heterokedastisitas. Berikut hasil uji heterokedastisitas:

\begin{tabular}{|c|c|}
\hline Model & Sig. \\
\hline (Constant) & 0.735 \\
\hline Price/Harga & 0.024 \\
\hline Quality/Kualitas & 0.063 \\
\hline
\end{tabular}

Sumber: Data Primerdiolah

Tabel diatas menunjukkan nilai signifikansi keempat variabel yaitu 
price/harga $\left(\mathrm{X}_{1}\right)$ sebesar 0,024 , quality/kualitas $\left(\mathrm{X}_{2}\right)$ sebesar 0,063, memiliki nilai sig $<5 \%(0,05)$. Hasil pengujian model regresi menunjukkan bahwa data tidak termasuk dalam data non heterokedastisitas.

\section{Uji Normalitas}

Pengujian normalitas dilakukan dengan meggunakan Kolmogrov smirnof test dengan melihat nilai Kolmogrov dan Asymp. Sig. untuk mengetahui data residual berdistribusi normal maka cukup dengan membandingkan nilai Asymp. Sig dengan tingkat error 5\% atau 0,05. Jika nilai Asymp. Sig. (2-tailed) $<0,05$ maka data berdistribusi tidak normal dan jika nilai Asymp. Sig. (2-tailed) $>0,05$ maka data residual berdistribusi normal.

Hasil analisis menunjukan bahwa nilai Asymp. Sig. (2-tailed) $>5 \%$ atau 0,05 yang mana nilai Asymp. Sig. (2-tailed) sebesar 0,749. Hal ini menunjukkan bahwa data residual terdistribusi normal sehingga prasyarat uji normalitas telah dipenuhi.

\section{Analisis Regresi Linier Berganda}

Hasil analisis regresi linier berganda terhadap kepuasan (Y) dan variabel yang mempengaruhinya (Price harga, Quality/Kualitas) ditunjukan oleh hasil perhitungan seperti tabel berikut:

\section{Analisis Regresi Linier Berganda}

\begin{tabular}{|c|c|c|c|c|c|c|c|c|}
\hline \multirow{3}{*}{\multicolumn{2}{|c|}{ Model }} & \multirow{2}{*}{\multicolumn{2}{|c|}{$\begin{array}{c}\text { Unstandardized } \\
\text { Coefficients }\end{array}$}} & \multirow{3}{*}{$\begin{array}{c}\text { Standardized } \\
\text { Beta }\end{array}$} & \multirow[t]{3}{*}{$\mathrm{t}$} & \multirow[t]{3}{*}{ Sig. } & \multicolumn{2}{|c|}{ Collinierity Statsitic } \\
\hline & & & & & & & \multirow{2}{*}{ Tolerance } & \multirow{2}{*}{ VIF } \\
\hline & & B & $\begin{array}{l}\text { Std. } \\
\text { Error }\end{array}$ & & & & & \\
\hline \multirow[t]{3}{*}{1} & (Constant) & 0.850 & 2.491 & & 0.341 & 0.735 & & \\
\hline & Price/Harga & 0.580 & 0.244 & 0.416 & 2.377 & 0.024 & 0.600 & 1.666 \\
\hline & $\begin{array}{l}\text { Quality } \\
\text { /Kualitas }\end{array}$ & 0.325 & 0.168 & 0.339 & 1.937 & 0.063 & 0.600 & 1.666 \\
\hline
\end{tabular}

Dependent Variable : Kepuasan

Dari tabel diatas menunjukkan bahwa persamaan regresi berganda yang diperoleh dari hasil analisis yaitu:

$$
Y=0.850+0.580 X_{1}+0.325 X_{2}(4.9)
$$

Dari persamaan regresi tersebut mempunyai makna sebagai berikut:

a. Konstanta $\left(\beta_{0}\right)=0.850$ Artinya jika price/harga $\left(\mathrm{X}_{1}\right)$, quality/kualitas $\left(\mathrm{X}_{2}\right)$, sebesar 0 (nol) dengan konstanta sebesar 0.850 , maka kepuasan pengujung (Y) akan sebesar 0.850 .

b. Nilai koefisi en $\beta_{1}=0.580$ artinya jika Price/harga pada hasil olahan 
laut yaitu kepitng mangalami kenaikan sebesar satu satuan sementara variabel bebas lainnya dianggap tetap, maka akan menyebabkan kenaikan pada kepuasan konsumen terhadap hasil olahan laut sebesar 0.196.

c. Nilai koefisien $\beta_{2}=0.325$ artinya jika quality/kualitas pada hasil olahan laut yaitu kepiting mengalami kenaikan sebesar satu satuan sementara variabel bebas lainnya dianggap tetap, maka akan menyebabkan kenaikan pada kepuasan konsumen terhadap hasil olahan laut sebesar 0.325 .

\section{Uji T}

Uji $t$ atau bisa disebut sebagai pengujian hipotesis parsial yang mana digunakan untuk menguji pengaruh dari masing-masing varibel bebas yaitu Price/harga (X1) dan Quality/kualitas (X2) terhadap kepuasan konsumen (Y).

Pengujian secara parsial ini menggunakan uji t dengan kaidah $\mathrm{H}_{0}$ diterima $\mathrm{H}_{1}$ ditolak dan melihat signifikan dengan error 0,05 dan atau menggunakan penentuan nilai kritis $t_{\text {hitung }}>t_{\text {tabel }}$.

1. Pengaruh price/harga $\left(\mathrm{X}_{1}\right)$ terhadap kepuasan konsumen $(\mathrm{Y})$ Berdasarkan hasil perhitungan pada variabel price/harga diperoleh signifikan 0.24. Karena nilai signifikan lebih kecil dari 0,05, maka $\mathrm{H}_{0}$ ditolak $\mathrm{H}_{\mathrm{a}}$ diterima. Variabel $\mathrm{X}_{1}$ mempunyai $t_{\text {hitung }}$ yakni 2.377 dengan $t_{\text {tabel }}$ 1.697. Jadi $t_{\text {hitung }}>t_{\text {tabel }}$ maka dapat disimpulkan bahwa variabel atraction/atraksi $\left(\mathrm{X}_{1}\right)$ memiliki pengaruh signifikan secara parsial terhadap kepuasan pengunjung (Y).

2. Pengaruh quality /kualitas $\left(\mathrm{X}_{2}\right)$ terhadap kepuasan pengunjung (Y) Berdasarkan hasil perhitungan pada variabel quality/kualitas diperoleh nilai signifikan 0.63 . Karena nilai signifikan lebih lebih besar dari 0,05 , maka $\mathrm{H}_{0}$ diterima $\mathrm{H}_{\mathrm{a}}$ ditolak. Variabel $\mathrm{X}_{2}$ mempunyai $t_{\text {hitung }}$ yakni 1.937 dengan $t_{\text {tabel }}$ 1.697. Jadi $t_{\text {hitung }}<$

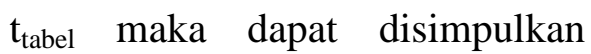
bahwa variabel quality/kualitas $\left(\mathrm{X}_{2}\right)$ tidak memiliki pengaruh signifikan secara parsial terhadap kepuasan pengunjung(Y).

\section{Uji F}

\section{Berikut Hasil Uji F}

Hasil Analisis Regresi Secara Simultan

Model Summary ${ }^{\mathrm{b}}$

\begin{tabular}{|l|l|l|l|l|}
\hline $\begin{array}{l}\text { Mo } \\
\text { del }\end{array}$ & $\mathrm{R}$ & $\begin{array}{l}\mathrm{R} \\
\text { Squ } \\
\text { are }\end{array}$ & $\begin{array}{l}\text { Adjus } \\
\text { ted R } \\
\text { Squar } \\
\mathrm{e}\end{array}$ & $\begin{array}{l}\text { Std. } \\
\text { Error } \\
\text { of the } \\
\text { Estim } \\
\text { ate }\end{array}$ \\
\hline 1 & $\begin{array}{l}.68 \\
3^{\mathrm{a}}\end{array}$ & .467 & .430 & $\begin{array}{l}1.650 \\
32\end{array}$ \\
\hline
\end{tabular}

a. Predictors: (Constant), Price,Qualitty

b. Dependent Variable:KEPUASAN

ANOVA $^{\text {b }}$
\begin{tabular}{|l|l|l|l|l|l|}
\hline Model & Su & D & Me & F & Si \\
\hline
\end{tabular}




\begin{tabular}{|c|c|c|c|c|c|c|}
\hline & $\begin{array}{l}\mathrm{m} \\
\text { of } \\
\text { Squ } \\
\text { ares }\end{array}$ & $\mathrm{F}$ & $\begin{array}{l}\text { an } \\
\mathrm{Sq} \\
\text { uar } \\
\mathrm{e}\end{array}$ & & $\mathrm{g}$ \\
\hline 1 & $\begin{array}{l}\text { Regr } \\
\text { essio } \\
\mathrm{n}\end{array}$ & $\begin{array}{l}69.0 \\
72\end{array}$ & 2 & $\begin{array}{l}34 . \\
53 \\
6\end{array}$ & $\begin{array}{l}12 . \\
680\end{array}$ & $\begin{array}{l}.0 \\
00 \\
\mathrm{a}\end{array}$ \\
\hline & $\begin{array}{l}\text { Resid } \\
\text { ual }\end{array}$ & $\begin{array}{l}78.9 \\
83\end{array}$ & $\begin{array}{l}2 \\
9\end{array}$ & $\begin{array}{l}2.7 \\
42\end{array}$ & & \\
\hline & Total & $\begin{array}{l}148 . \\
005\end{array}$ & $\begin{array}{l}3 \\
1 \\
\end{array}$ & & & \\
\hline
\end{tabular}

Berdasarkan hasil pengujian hipotesis dengan perhitungan analisis regresi berganda menggunakan SPSS diperoleh $F_{\text {hitung }}=12,680$ dengan nilai signifikan 0.000. jika hasil ini dibandingkan dengan $F_{\text {tabel }}$ pada degree of freedom $(n-k-1=29)$ ada probabilitas kesalahan 0,05 maka pada $F_{\text {tabel }}$ sebesar 4,17. Karena $F_{\text {hitung }}>F_{\text {tabel }}(12,680>4,17)$ dan probabilitas kesalahan 0,000 lebih kecil dari 0,05 maka dapat dikatakan bahwa terdapat pengaruh secara simultan antara, price/harga dan, quality/kualitas, terhadap kepuasan konsumen terhadap hasil olahan laut.

\section{KoefisienDeterminasi $\left(\mathbf{R}^{\mathbf{2}}\right)$}

Berdasarkan hasil pengolahan data dengan menggunakan SPSS dapat diperoleh hasil koefisien determinasi sebesar 0.467 atau 46,7\%. Dari penjelasan di atas dapat disimpulkan bahwa variasi variabel independen yang digunakan dalam penelitian ini, yaitu price/harga dan quality /kualitas sebesar $46,7 \%$ sedangkan sisanya $53,3 \%$ diterangkan oleh variabel lain yang tidak terdapat dalam model.

Nilai $R^{2}$ yang kecil berarti kemampuan variabel-variabel independen dalam menjelaskan variansi variabel dependen sangat terbatas. Meskipun nilai $\mathrm{R}^{2}$ yang diperoleh dari hasil analisis rendah bukan berarti hasil penelitiannya tidak bagus. Namun demikian, kita harus memahami bahwa rendahnya nilai $\mathrm{R}^{2}$ terjadi karena beberapa alasan. Menurut Widarjono (2013), bahwa nilai $\mathrm{R}$ Square yang tinggi adalah baik tetapi apabila diperoleh nilain $\mathrm{R}$ Square yang rendah bukanlah berarti hasil penelitian tersebut tidakbaik.

\section{PEMBAHASAN}

\section{Pengaruh price/harga terhadap Kepuasankonsumen}

Berdasarkan hasil penelitian ini dapat diungkapkan bahwa 32 responden yang telah diteliti merasa setuju dengan price/harga dari hasil olahan laut.

Penelitian ini juga bahwa hipotesis diterima yaitu harga memiliki pengaruh secara parsial terhadap kepuasan konsumen terhadap hasil olahan laut. Hal ini dapat kita lihat dari nilai signifikansi atraksi sebesar 0.024 lebih kecil dari 0.05 oleh karena itu atraksi memiliki pengaruh signifikan terhadap kepuasan pengunjung.

Pengaruh Quality /Kualitas Terhadap Kepuasan Konsumen. 
Berdasarkan hasil penelitian ini dapat diungkapkan bahwa 32 responden yang di teliti merasa setuju mengenai quality kualitas dari hasil laut.

Penelitian ini juga bahwa hipotesis diterima yaitu Quality /kualitas memiliki pengaruh secara parsial terhadap kepuasan konsumen terhadap hasil olahan laut. Hal ini dapat kita lihat dari nilai signifikansi Quality /kualitas sebesar 0.063 lebih besar dari 0.05 oleh karena itu Quality /Kualitas memiliki pengaruh signifikan terhadap kepuasan konsumen.

\section{SIMPULAN DAN SARAN}

\section{SIMPULAN}

Berdasarkan analisis dan pembahasan yang di uraikan pada bab sebelumnya, maka penulis dapat menarik kesimpulan sebagai berikut:

1. Secara individu (parsial) didapatkan hasil sebagai berikut:

a. Dari hasil penelitian ini menunjukkan bahwa Dari hasil penelitian ini menunjukkan bahwa price /harga memiliki pengaruh signifikan secara parsial terhadap kepuasan konsumen (Y).

b. Dari hasil penelitian ini menunjukkan bahwa quality /kualitas tidak memiliki pengaruh signifikan secara parsial terhadap kepuasan konsumen(Y).
2. Secara bersama-sama (simultan) didapatkan hasil bahwa terdapat pengaruh secara simultan antara, price /harga, quality /kualitas. terhadap kepuasan konsumen terhadap olahan kepiting di kota Tarakan.

3. Berdasarkan hasil perhitungan Rsquare sebesar 0.467 artinya kemampuan variabel independen ( price/harga, Quality/kualitas ) sebesar 0.467 atau $46,7 \%$. sedangkan sisanya $53,3 \%$ diterangkan oleh variabel lain yang tidak terdapat dalam model.

\section{SARAN}

Berdasarkan hasil analisis yang dilakukan, maka terdapat beberapa saran yang penulis sampaikan yaitu:

1. Bagi pemerintah pihak-pihak berwenang, untuk menambahkan fasilitas maupun sarana prasarana dan menambahkan kualitas sarana prasarana yang ada untuk mendorong dan memudahkan pengelolaan kepiting dalam produksinya.

2. Dilihat dari sisi pengelolaan lebih menjaga kebersihan dari produk- produknya sehingga kualitas dari produksinya lebih terjaga , serta dapat memberikan lebel dari hasil olahannya agar olahan tersebut dapat dikenali banyakorang.

3. Bagi peneliti selanjutnya diharapkan dapat lebih memperluas variabel bebas juga menyebarkan kuesioner 
tidak hanya berdasarkan hasil perhitungan sampel, jika perlu dilebihkan agar data yang tersebar dan diambil akan lebih mewakil populasi yang ada.

\section{DAFTAR PUSTAKA}

Apridar Et All. (2011). Ekonomi Kelautan Dan Pesisir. Graha Ilmu: Yogyakarta

Aufar, Arizali. (2014). FaktorFaktor yang Mempengaruhi Penggunaan Informasi Akuntansi Pada UMKM (Survei Pada Perusahaan Rekanan PT. PLN (Persero) di Kota Bandung)

Cahaya, A. (2015). Fishermen Community in the Coastal Area: A Note from Indonesian Poor Family. Procedia Economics and Finance, 26, 29-33.

California Environmental Associates. (2018). Trends in Marine Resources and Fisheries Management in Indonesia: A 2018 Review. Prepared with the support of the David and Lucile Packard Foundation.

Chen, J., \& Zheng, J. (2016). On farmers' educational problem in the construction of beautiful village -- A case study of Jinjiang City. SHS Web of Conferences.24, pp. 1-5. EDP Sciences.

Clifton, J., Tonts, M., \& Boruff, B. (2007). a Socio-Economic
Overview of the Coastal Communities Adjacent To the North-West Marine Region. Department of the Environment, Water, Heritage and the Arts.

David, G., Leandro, C., Almeida , O., \& Estupiñán, G. (2015). Market Formalization, Governance, and the Integration of Community Fisheries in the Brazilian Amazon. Society \& Natural Resources, 28(5), 513-529.

FAO. (2005). Increasing the contribution of small-scale fisheries to poverty alleviation and food security. FAO Technical Guidelines for Responsible Fisheries. No 10. (Vol. 10). FAO Technical Guidelines for Responsible Fisheries.

Fragouli, E., \& Theodoulou, P. (2015). The Way People And Societies Perceive The Nature And Context Of Risk Is Different, Due To Psychological And Cultural Issues. Journal of Economics And Business, XVIII(1), 2946.

Gasperz, V. (2005). Lean Sigma Approach. Jakarta: Penerbit Erlangga

Gremler, D., Bitner, M. J., \& Zeithaml, V. A. (2012). Services Marketing. NY: McGraw Hill 
Kerlinger. (2006). Asas-Asas Penelitian Behaviour. Edisi 3, Cetakan 7. Yogyakarta: Gadjah Mada University Press.

Kotler, P. and Keller, K.L. (2009). Marketing Management: 13th Edition. New Jersey: Upper Saddle River

Kyvelou, S., \& Ierapetritis, D. (2020).

Fisheries sustainability through soft multi-use maritime spatial planning and local development comanagement: Potentials and challenges in Greece. Sustainability (Switzerland), 12, 1-26.

Leasiwal, T. C. (2017). Determinants of Fishermen Income in Regency of West Seram, Maluku. Cita Ekonomika, XI(1), 1-14.

Lein, A., \& Setiawina, N. (2018). Factors affecting the fishermen household income and welfare. International Research Journal of Management, IT and Social Sciences, 5(4), 80-90.

Pratiwi, Sulistya, \& Rahmawati, Meylin. (2018). Nilai Tambah Pada Industri Ikan Kering Tipis Di Juata Laut. Jurnal Ekonomi Pembangunan, 7(2), $223-238$.

Purwoko. B. A. (2000). Kepuasan dan Loyalitas: Perspektif
Kualitas Layanan. Jakarta:

Komunika Jaya Pratama.

Sugiyono. (2013). Metode

Penelitian Kuantitatif Untuk Manajemen dan Bisnis. Bandung: Penerbit CV. Alfabeta.

Sunarto. (2003). Perilaku Konsumen. Yogyakarta : Amus Yogyakarta dan CV. Ngeksigondo Utama.

Supranto, J. (2006). Pengukuran Tingkat Kepuasan Pelanggan Untuk Menaikkan Pangsa Pasar. Jakarta: PT. Rineka Cipta.

Tjiptono, Fandy. (2008). Strategi Pemasaran. Edisi Kedua. Yogyakarta: Andi Offset.

Yunita, E., Sinaga, R., \& Pargito, P. (2018). Kondisi Sosial Ekonomi Masyarakat Nelayan Di Pantai Labuhan Jukung Krui Pasca Terbentuknya Kabupaten Pesisir Barat. Jurnal Studi Sosial, 6(1), 1-10.

Zamroni, A., Apriliani, T., Yusuf, R., \& Kurniasari, N. (2019). Enhanching small-scale community for coastal management in Puntondo Bay, Indonesia. 370, pp. 1-8. IOP Conference Series: Earth and Environmental Science. 